\title{
6.13 Методичні засади використання фізико-технічних відкриттів в курсі медичної та біологічної фізики майбутніх лікарів
}

Історичний розвиток медицини постійно і зростаючими темпами зазнає закономірного впливу базових фундаментальних природничих дисциплін. Безумовно, що основною серед фундаментальних наук $є$ фізика, яка займає (з XVII ст. ) лідируючі позиції, а згодом біофізика та медична фізика (з XIX-XX ст. ), як прикладні розділи фізики, в яких фундаментальні закони та досягнення фізики застосовуються для пояснення процесів, що відбуваються у медико - біологічних системах, зокрема - людському організмі, з метою їх використання для вирішення практичних завдань медицини, перш за все, системи охорони здоров'я людини [483].

Варто зазначити, що завдячувати потрібно вченим фізикам, біологах, фізіологам, медикам, наукові відкриття яких, дали поштовх в розвитку медицини. Серед лауреатів Нобелівської премії в галузі медицини та фізіології є багато вчених фізиків - Арчібальд Хілл (1922рік, Англія) - за відкриття у галузі теплотворення м'язів, Георг Бекеші (1961рік, Угорщина) - за відкриття фізичних механізмів подразнення равликом, біофізик Моріс Вілкінс (1962рік, Англія) - за відкриття, що стосуються молекулярної структури нуклеїнових кислот та їх значення для передачі інформації у живій матерії, біофізик Алан Ходжкін (1963рік, Англія) - за відкриття іонних механізмів, що беруть участь у збудженні та гальмуванні. Макс Дельбрук (1969рік, США) - за відкриття механізмів реплікації і генетичної структури вірусів, Розалін Ялоу (1977рік, США) - за розвиток радіологічних методів визначення пептидних гормонів, А. М. Кормак (1979 рік, США) та Годрі Хаунсфілд (1979, Англія) - за розробку методів рентгенівської комп'ютерної томографії, Девід Хьюбелл (1981 рік, США) - за відкриття, пов’язані з обробкою інформації у зоровому аналізаторі. Пітер Менсфілд (2003 рік, Великобританія,) та хімік і біофізик Пол Лотербур (2003 рік, США) за дослідження в галузі магнітнорезонансної томографії [484].

3 іншого боку, існують беззаперечні історичні факти про те, що професором медицини Гілбертом ( XVII ст., Англія) були закладені основи магнітостатики, і в 
той же час лікарем Гальвані (XVII ст., Італія) закладений початок розвитку уявлень про електричні поля в біологічних системах, так звана «тваринна електрика», що в результаті призвело до створення електромагнітної теорії у працях фізиків Фарадея та Максвелла.

Професор медицини Даніель Бернуллі та математик Леонард Ейлер (середина XVII ст, Швейцарія) заклали основи гідродинаміки. Професор медицини Томас Юнг (початок ХІХст, Англія) розробив хвильову теорію світла, ввів поняття механічної енергії та модуля пружності, а професор медицини Жан Пуазейль та німецький фізик Готтгільф Гаген (середина ХІХст, Франція, Німеччина) описали закон руху рідини, що використовується для визначення в'язкості і швидкості руху в капілярних трубках. Лікар Юліус Роберт Майер, фізик Джеймс Джоуль та фізик і лікар Герман Гельмгольц в середіні XIX століття відкрили закон збереження енергії- універсальний закон перетворення енергії у живій природі. Це і $є$ відповідь на питання, а що ж медики зробили для розвитку фізики на початковому етапі iї становлення, і звісно ж всі вони достойні найвищої відзнаки і в галузі фізики, поєднання знань 3 фізики і медицини привели вчених до фундаментальних відкриттів.

Історично від початку елементарного фізичного дослідження в стародавній Греції, поняття «фізюс» означало дослідження природи і перші лікарі, які мали справу з природою здоров'я чи захворювання людини, також називали себе «фізюс» [485]. В ті часи не існувало істотної диференціації на фізиків і медиків (вчені одночасно були і лікарями і фізиками), що дало можливість стрімко розвиватись і фізичній і медичній науці паралельно, створюючи природничонаукові теорії на основі єдиних принципів існування та розвитку всього матеріального світу як для опису явищ неживої природи (неорганічного світу), так і живої природи (органічного світу).

Сьогодні, спостерігається все більша диференціація наук, і майбутній лікар, має можливість ознайомитись 3 фізико-технічними відкриттями вчених на двох рівнях: допрофесійної підготовки (ЗСО) та професійної підготовки (3ВО), що відповідає принципу неперервності освіти при підготовці фахівців медичної галузі. 
В допрофесійній підготовці учні 10-11 класів можуть обрати природничоматематичний напрям профільного навчання в середніх навчальних закладах (академічних ліцеях) Природничо-математичний напрям профільного навчання включає в себе такі навчальні профілі: фізико-математичний, хіміко - біологічний, хіміко - фізичний. Профільне навчання забезпечує створення оптимальних умов для виявлення задатків, нахилів і здібностей кожного учня, та створення умов відповідно до їхнього самовизначення та професійної орієнтації.

Обираючи один із навчальних профілів природничо-математичного напрямку, майбутнім фахівцям медичної галузі ми рекомендуємо обрати цикл курсів «Біологічна і медична фізика» (рекомендований МОН України, 2019 рік):

- Вступ до біофізики. Біомеханіка твердих тіл і рідин»,

- Фізичні основи гемодинаміки. Термодинаміка. Фізичні процеси в біомембранах.

- Електрика і магнетизм в медицині.

- Механічні коливання і хвилі. Акустика. Оптика. Елементи квантової біофізики і основи дозиметрії.

Цикл курсів передбачає поглиблення і розширення пізнавальних інтересів учнів, формування наукового світогляду учнів, ознайомлення 3 історією відкриттів та сучасними напрямками розвитку медичної та біологічної фізики, забезпечення прикладної і початкової професійної спеціалізації навчання.

На етапі професійної підготовки студенти 1 курсу вищих медичних закладів вивчають дисципліну «Медична та біологічна фізика», де передбачено вивчення явищ живої природи, які відбуваються на всіх іiі рівнях організації, починаючи від молекул і клітин та закінчуючи біосферою в цілому; механізмів дії зовнішніх полів на організм людини, які лежать в основі функціонування сучасної електронної медичної апаратури та визначають головні принципи їі роботи і використання [486 - 488]. Діючою програмою ( 2019 р.) передбачено вивчення наступних змістових модулів:

- Основи математичної обробки медико - біологічних даних

- Основи біологічної фізики 
- Електронна медична апаратура

- Основи медичної оптики та радіаційної медицини

У відповідності до закону України «Про вищу освіту» пріоритетним напрямком $\epsilon$ професійно-орієнтоване навчання, яке визначає компетентність як динамічну комбінацію знань, умінь і практичних навичок, способів мислення, професійних, світоглядних і громадянських якостей, морально-етичних цінностей, що формує здатність особи здійснювати професійну діяльність [489].

Для реалізації завдань професійно-орієнтованого навчання нами створена структурно - функціональна модель: «Методичні засади використання фізикотехнічних відкриттів у навчанні медичної та біологічної фізики майбутніх лікарів. В даній моделі (Рис. 1) запропоновані, на нашу думку, найбільш ефективні, дві сучасні технології навчання, які дозволяють розкрити питання фізико-технічних відкриттів та їх використання як у допрофесійній так і в професійній підготовці майбутніх лікарів. До них належать: кейс - метод та презентації наукових трендів.

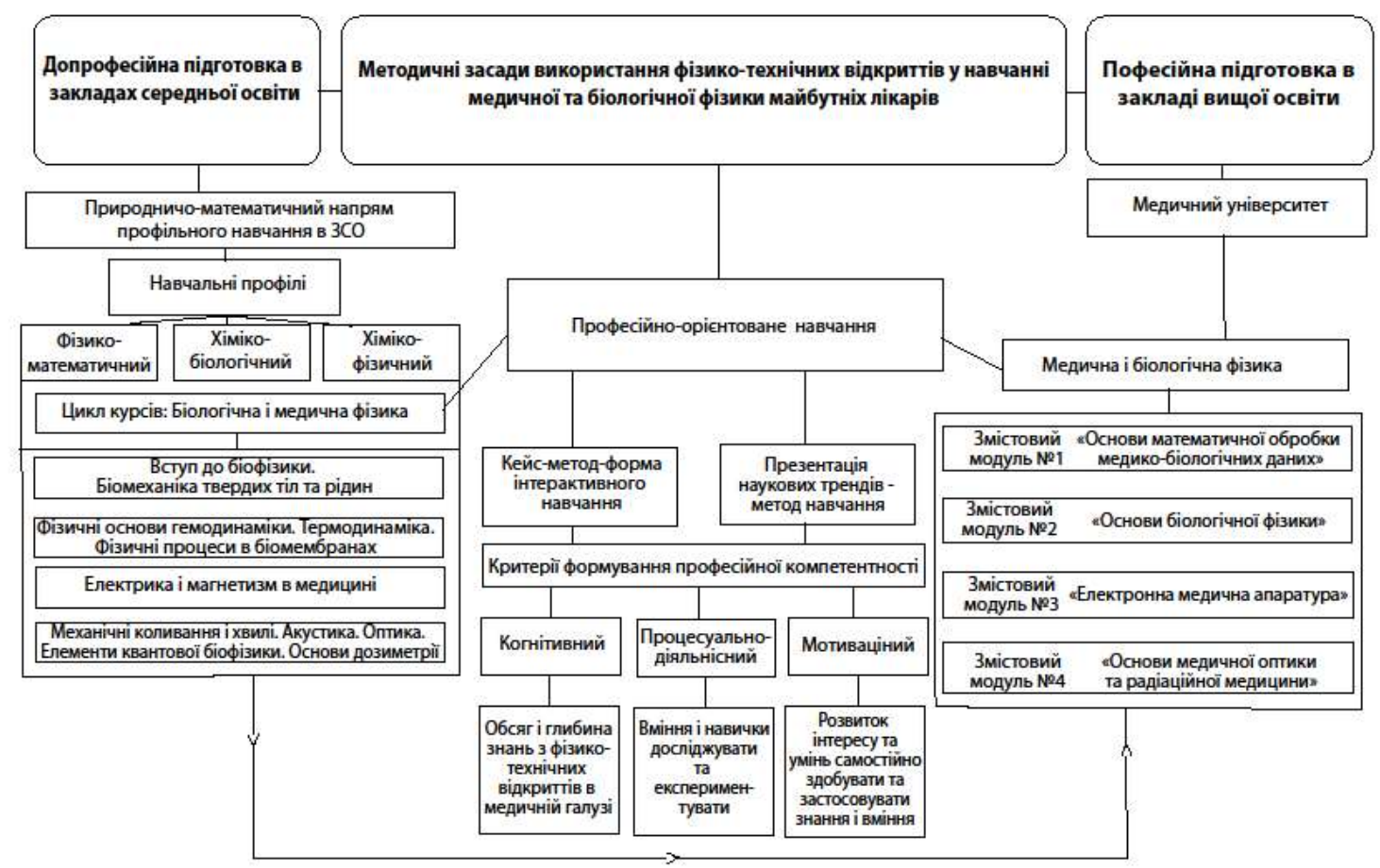

Рис.1. Структурно-функціональна модель реалізації методичних засад використання фізико-технічних відкриттів у навчанні медичної та біологічної фізики майбутніх лікарів. 
Кейс метод (Case study- метод аналізу ситуацій ) є ефективним методом вивченні фундаментальних наук в медицині, зокрема в біологічній і медичній фізиці, яка може стати початковим етапом застосування методу аналізу ситуацій у навчанні майбутніх лікарів. Використання методу Case study на практичних заняттях за змістовими модулями «Основи біологічної фізики», «Електронна медична апаратура», «Основи медичної оптики та радіаційної медицини» дозволяє підвищити пізнавальний інтерес до дисципліни, сприяє розвитку дослідницьких, творчих навиків i набуття професійних компетенцій студентів-медиків. Особливою рисою методу є створення проблемної ситуації на основі фактів 3 реального наукового життя фізиків, що здійснили відомі відкриття в науці. Шлях до відкриття пов'язаний з науковою діяльністю не одного покоління вчених, де кожен робить свій внесок, не завжди оптимальний, але в повній мірі той, що прискорює відкриття. Case study в конкретних ситуаціях, які розроблені 3 фактичного матеріалу, саме занурення в історію відкриттів, розгляд конкретних ситуацій, які привели до відкриття, дає можливість на практичних заняттях зі студентами перейти від істини плюралістичної до істини, що дає однозначну відповідь на поставлене питання. Метод дає можливість акцент навчання переносити не лише на оволодіння готовими знаннями, а на їх вироблення, на спільну партнерську роботу студента та викладача, який від трансляції знання, що характерно класичному навчанню, переходить до управління дослідницькою і пошуковою роботою студента. Результатами застосування методу $є$ не тільки знання, але й навики професійної діяльності. Метод Case study розвиває такі професійні компетенції особистості майбутнього лікаря, як здатність до аналізу і діагностики проблем, вміння чітко формулювати і висловлювати свою позицію, спілкуватися, дискутувати, сприймати й оцінювати інформацію, яка надходить у вербальній і невербальній формах.

Для розвитку інтересу та формуванню умінь самостійно здобувати знання студентам, використовуючи метод Case study у навчанні «Медичної та біологічної фізики», можна запропонувати теми вивчення наукових відкриттів таких вчених: «Ернст Вебер та Густав Фехнер - творці психо-фізичного закону 
сприйняття звуку», «Томас Юнг - творець хвильової теорії світла», «Даніель Бернуллі та Леонард Ейлер - творці основ гідродинаміки.,«Юліус Роберт Майер, Джеймс Джоуль та Герман Гельмгольц - відкривачі закону збереження енергії», «Вільям Ейнтховен - творець методу електрокардіографії», «Алан Кормак та Годрі Хаунсфілд - творці методу рентгенівської комп’ютерної томографії», «Пітер Менсфілд та Пол Лотербур - творці методу магнітно-резонансної томографії.» та інші. Однією з найкращих форм використання методу Case study при вивченні фізико - технічних відкриттів є кейси-спогади, які характерні тим, що в них час прокручується назад, що дає можливість аналізу ситуації в минулому, хоч самі спогади можуть бути безсистемні, фрагментарні, що створює певні труднощі з відновленням подій. Аналіз кейса зводиться до реконструкцій ситуацій, її осмислення в аспекті тієї чи іншої парадигми.

В теорії і практиці даного питання важливе місце займають види аналізу кейсів: проблемний, причинно-наслідковий, прагматичний, аксіологічний, ситуаційний, прогностичний, програмно-цільовий. Формально можна виділити такі етапи кейсу: ознайомлення студентів 3 текстом кейсу, аналіз кейсу, організація обговорення кейса, дискусії, презентації, оцінювання учасників дискусії і підведення підсумків дискусії. Практика підтверджує, що найчастіше ознайомлення 3 текстом кейсу здійснюється до обговорення і реалізується як самостійна робота студентів, де в першу чергу, слід виявляти ключові проблеми кейсу та зрозуміти, які саме з представлених даних важливі для його вирішення. Завершальним етапом методу Case study є оцінювання учасників, враховуючи дидактичні принципи навчання: об’єктивність, обгрунтованість, систематичність, всебічність, оптимальність. Метод Case study - це особливий і гнучний педагогічний ресурс або універсальний засіб для реалізації завдань професійно-орієнтованого навчання і є однією з сучасних ефективних технологій навчання при вивченні фізико-технічних відкриттів у навчанні майбутніх лікарів [490].

Презентації наукових трендів $є$ ефективним методом сучасних технологій навчання. Однією з традиційних форм організації навчання студентів медиків у 
ЗВО залишається лекція, що є дієвим способом передавання знань. Сучасну лекцію ми вже не уявляємо без використання презентації, яка включає в себе три основні компоненти: промова лектора, слайди, додаткові матеріали (студент отримує індивідуально список літератури та інших посилань, що містять деталі інформації, що презентуються). Головним в презентації є промова лектора, а зображення на екрані є допоміжним. Презентації дають можливість поєднувати слайди різного змісту і форми, які мають бути наповнені науковими трендами (тенденціями в наукових відкриттях). Використання презентацій наукових трендів на практичних заняттях також забезпечує обсяг і глибину знань з фізикотехнічних відкриттів в медичній галузі та формує у студентів вміння та навички досліджувати та експериментувати. Для прикладу, пропонуємо тенденції розвитку досліджень в діагностичній радіології, які можуть стати базовими для використання кейс-методу та в підготовці презентацій наукових трендів:

\begin{tabular}{|c|c|}
\hline Рік & Зміст відкриття \\
\hline $1859 \mathrm{p}$. & $\begin{array}{l}\text { Німецький математик і фізик Ю. Плюккер досліджував катодні } \\
\text { промені та їх відхилення в магнітному полі }\end{array}$ \\
\hline $\begin{array}{l}1881- \\
1889 p p .\end{array}$ & $\begin{array}{l}\text { Український фізик І. Пулюй (одноліток К Рентгена) сконструював } \\
\text { катодну лампу, яка привела до відкриття X - променів, досліджував } \\
\text { іонізуючу їх здатність, природу і механізм утворення. І. Пулюй } \\
\text { опублікував статтю з описом катодної трубки, що випромінює Х - } \\
\text { промені, а Лондонське фізичне товариство надрукувало його } \\
\text { монографію про катодні промені }\end{array}$ \\
\hline $1895 \mathrm{p}$ & 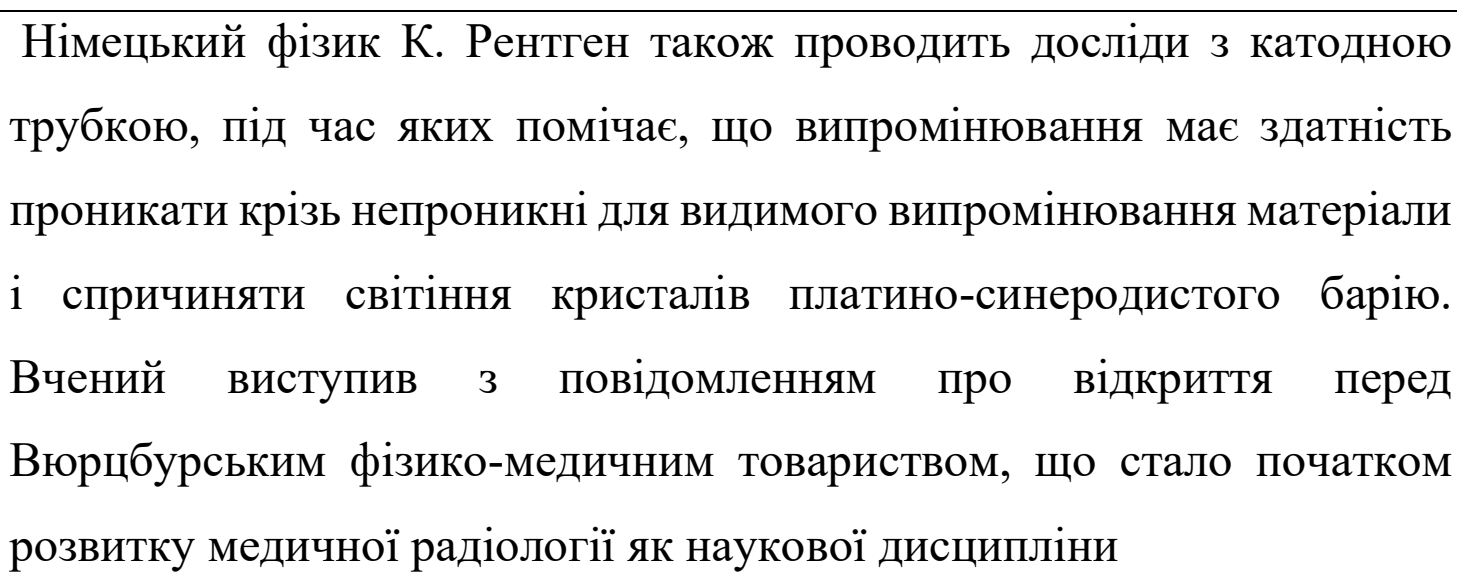 \\
\hline
\end{tabular}




\begin{tabular}{|c|c|}
\hline $1901 \mathrm{p}$. & $\begin{array}{l}\text { К. Рентген отримав першу в історії Нобелівську премію з фізики за } \\
\text { відкриття Х-променів, які потім за рішенням. Першого міжнародного } \\
\text { з'їзду з рентгенології назвали рентгенівськими }\end{array}$ \\
\hline $912 \mathrm{p}$. & $\begin{array}{l}\text { Німецький фізик Макс фон Лауе в дослідах } 3 \text { інтерференції та } \\
\text { дифракції показав, що рентгенівське випромінювання } \\
\text { електромагнітним і відрізняється від світла лише меншою довжиною } \\
\text { хвилі }\end{array}$ \\
\hline 1914 p. & $\begin{array}{l}\text { он Лауе отримав Нобелівську премію за відкриття дифракції } \\
\text { івських променів на кристалах }\end{array}$ \\
\hline 1939 p. & $\begin{array}{l}\text { Американський фізик Ернесто Лоуренс } \quad \text { запропонував } \\
\text { використовувати прискорення елементарних частинок для надання їм } \\
\text { високих енергій і створює циклотрон, що став одним } 3 \text { джерел } \\
\text { отримання штучних радіоактивних елементів і отримав Нобелівську } \\
\text { премію з фізики за цей винахід }\end{array}$ \\
\hline 1944 p. & $\begin{array}{l}\text { ик Е.К. Завойський відкрив явище електронного } \\
\text { резонансу }\end{array}$ \\
\hline $6 \mathrm{p}$. & $\begin{array}{l}\text { Американські фізики Ф. Блох та Е.М. Парселл незалежно один від } \\
\text { одного дослідили ядра деяких атомів в магнітному полі, які під дією } \\
\text { зовнішнього ЕМП здатні поглинати енергію, а потім випромінювати } \\
\text { ії у вигляді радіосигналу }\end{array}$ \\
\hline $1952 \mathrm{p}$ & $\begin{array}{l}\text { мериканські фізики Ф. Блох та Е.М. Парселл отримали Нобелівську } \\
\text { ремію за відкриття фундаментального фізичного явища - ядерного } \\
\text { агнітного резонансу }\end{array}$ \\
\hline 1963 p. & $\begin{array}{l}\text { В журналі з прикладної фізики з'явилася стаття маловідомого тоді } \\
\text { американського фізика } \text { А. Кормака, в якій він запропонував } \\
\text { математичний метод для визначення поглинання рентгенівських } \\
\text { променів біологічними тканинами, котрий пізніше, після появи } \\
\text { швидких комп'ютерів, отримав назву КТ-скануванням }\end{array}$ \\
\hline
\end{tabular}




\begin{tabular}{|c|c|}
\hline p. & $\begin{array}{l}\text { Англійський фізик-інженер } Г \text {. Хаунсфілд, розробив схожу } \\
\text { яатематичну модель для гамма }- \text { променів, використовуючи } \\
\text { Іотужніший комп'ютер для обробки інформації }\end{array}$ \\
\hline 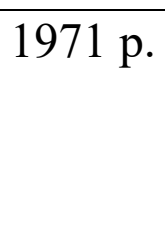 & $\begin{array}{l}\text { Зстановлений перший клінічний томограф в Уімблдонському } \\
\text { шпиталі (Великобританія) і почалися дослідження хворих } 3 \\
\text { гухлинами мозку та іншими захворюваннями }\end{array}$ \\
\hline $3 n$ & $\begin{array}{l}\text { В журналі «Nature» з'явилася стаття американського хіміка і } \\
\text { біофізика П. Лотербура про створення зображення за допомогою } \\
\text { індукованої локальної взаємодії неоднорідного магнітного поля } 3 \\
\text { ядрами атомів. Це дозволило П. Лотербуру створити перший } \\
\text { магнітно-резонансеий томограф. }\end{array}$ \\
\hline 1979 p. & $\begin{array}{l}\text { ериканський фізик А. М. Кормак та англійський фізик } \\
\text { Каунсфілд отримали Нобелівську премію в галузі фізіології та } \\
\text { дицини за розробку рентгенівської комп’ютерної томографії. }\end{array}$ \\
\hline $03 p$ & $\begin{array}{l}\text { Британський фізик П. Менсфілд та американський біофізик П. } \\
\text { Лотербур отримали Нобелівську премію за дослідження в галузі } \\
\text { магнітно-резонансної томографії }\end{array}$ \\
\hline
\end{tabular}

Важливою функцією наукових трендів $є$ своєчасне ознайомлення студентів з сучасними тенденціями розвитку, зокрема, в діагностичній радіології спираючись на інформаційні технології, які розвиваються і впливають на суспільне життя, за допомогою мобільних гаджетів можна забезпечити прямий зв’язок пацієнта з віддаленим центром діагностики. Сучасним трендом в радіології є вирішення проблеми консультацій пацієнтів на відстані, яким займається телемедицина, як один 3 напрямків практичної медицини, що тісно пов’язаний з сучасними цифровими технологіями і розвивається дуже швидкими темпами в світі [491].

Запропонована нами модель включає навчання учнів та студентів на всіх етапах підготовки, $€$ ефективною $\mathrm{i}$ позитивно впливає на формування професійних компетентностей сучасних лікарів. 